\title{
Penggunaan metode pembelajaran kooperatif dalam usaha meningkatkan hasil belajar gerak dasar melompat peserta didik kelas $\mathrm{V}$
}

\section{The use of cooperative learning methods in an effort to improve learning outcomes of basic jumping movements for fifth grade students}

\author{
Djoko Nugroho ${ }^{1}$ \\ ${ }^{1}$ SDN Sungai Langsat Kabupaten Banjar \\ Email: djokonugroho1986@gmail.com ${ }^{1}$
}

\section{INFO ARTIKEL}

Diterima : 30 April 2021

Disetujui : 27 Mei 2021

Tersedia secara Online Mei 2021

\author{
Alamat Korespondensi: \\ Djoko Nugroho \\ SDN Sungai Langsat Kabupaten Banjar \\ Jl. Desa Sungai Langsat, Sungai \\ Langsat, Kec. Simpang Empat, Kab. \\ Banjar Prov. Kalimantan Selatan \\ E-mail: \\ djokonugroho1986@gmail.com
}

\begin{abstract}
ABSTRAK
Tujuan penelitian ini adalah untuk meningkatkan hasil pembelajaran gerak dasar melompat melalui penggunaan Metode Kooperatif Pada Peserta Didik Kelas V (lima) SDN Sungai Langsat Kabupaten Banjar. Metode yang digunakan dalam penelitian ini adalah metode penelitian tindakan kelas (PTK) yaitu penelitian dalam bentuk reflektif. Pengamatan pada waktu proses belajar mengajar berlangsung dan analisis data dilakukan berdasarkan pengamatan oleh supervisor. Subjek penelitian ini adalah peserta didik kelas V (lima) di SD SDN Sungai Langsat Kabupaten Banjar Tahun ajaran 2019/2020. Jumlah peserta didik yang dijadikan subjek penelitian sebanyak 18 orang terdiri dari 11 peserta didik putra dan 7 peserta didik putri. Proses peningkatan kemampuan dan hasil belajar pada materi gerak dasar lompat sesudah diterapkan metode pembelajaran Kooperatif mengalami peningkatan. Berdasarkan analisis data ditemukan bahwa hasil penilaian kemampuan peserta didik menunjukkan peningkatan kemampuan peserta didik ditunjukkan dari hasil penilaian pengamatan awal 64 (kurang), pertemuan Siklus I (satu) 68 (cukup) dan pertemuan siklus II (dua) 84,95 (sangat baik).
\end{abstract}

Kata kunci: keterampilan gerak dasar melompat, metode kooperatif dan hasil belajar.

The purpose of this study was to improve the results of learning the basic motion of jumping through the use of the Cooperative Method for Class V (five) SDN Sungai Langsat, Banjar Regency. The method used in this research is classroom action research (CAR), namely research in a reflective form. Observations during the teaching and learning process took place and data analysis was carried out based on observations by supervisors. The subjects of this study were students in grade V (five) at SDN Sungai Langsat Elementary School, Banjar Regency in the 2019/2020 academic year. The number of students who were used as research subjects was 18 people consisting of 11 male students and 7 female students. The process of increasing the ability and learning outcomes in the basic jumping motion material after the application of the cooperative learning method has increased. Based on the data analysis, it was found that the results of the student's ability assessment showed an increase in the ability of students as indicated by the results of the initial observation assessment 64 (less), the meeting in Cycle I (one) 68 (enough) and the meeting in cycle II (two) 84.95 (very good).

Key words: basic jumping motion skills, cooperative methods and learning outcomes. 


\section{PENDAHULUAN}

Pelajaran melompat di kelas V (lima) masih berbentuk aneka ragam tugas-tugas gerak yang dilakukan dengan melompat-lompat. Tujuannya adalah memperkaya perbendaharaan gerak peserta didik melalui serangkaian proses, perbendaharaan gerak peserta didik akan semakin kaya dan lambat laun akan menuju teknik gerak yang diinginkan. Berbagai variasi gerakan melompat seperti lompat ke depan, lompat ke belakang, lompat ke samping, melompat, dan lain-lain, dikemas dalam bentuk permainan yang menggembirakan. Kegiatannnya dimanipulasi dengan gerakan sederhana, tidak terlalu terstruktur dan disesuaikan dengan tingkat kemampuan serta karakteristik peserta didik. Anda pasti tahu bahwa pada peserta didik kelas V (lima) ( \pm 8-10 tahun) koordinasi gerakannya masih belum sempurna. Oleh karena itu jangan diberikan tugas gerak yang berat. Tugas gerak yang berat memungkinkan terjadinya kelainan postur tubuh. Untuk peserta didik kelas V (lima) perlu gerakan-gerakan yang ringan, lincah, dan dinamis. Gerakan demikian sangat menyenangkan, efektif untuk mengembangkan koordinasi dan merangsang pertumbuhan fisik peserta didik.

Agar peserta didik mau dan senang melompat-lompat terutama melompat harus ada motivasi (Mashud, 2020). Seringkali sekedar tanda-tanda di tanah dan garis-garis di lantai sudah cukup memberikan rangsangan. Pendekatan inilah yang sampai sekarang ini berlangsung karena kurang disenangi, lalu hampir tidak pernah diajarkan. Apakah langkah sekarang, untuk menyesuaikan dengan karakteristik dan perkembangan peserta didikpeserta didik Sekolah Dasar, maka pembelajran harus dimodifikasi. Penekanannya pada aspek bermain, karena ini merupakan bagian dari kehidupan peserta didik. Terutama bagi peserta didik yang kurang berbakat, atletik disajikan dalam bentuk permainan menjadi kegiatan yang menarik. Tujuan modifikasi atletik ini ialah agar sejak awal unsur-unsur gerak dasar lokomotor (berpindah tempat) dapat diperkenalkan kepada peserta didik secara menarik dan menyenangkan. Seorang guru pendidikan jasmani dituntut harus bisa menjalankan tugasnya sesuai dengan tujuan pendidikan jasmani (Mashud, 2018). Kurangnya kreatifitas dan inovasi metode pembelajaran dan media pembelajaran yang dikembangkan oleh guru pendidikan jasmani membuat pelajaran pendidikan jasmani menjadi tidak efektif dan tidak berkualitas. Sering terjadi dalam pembelajaran pendidikan jasmani, olahraga dan kesehatan di Sekolah Dasar (SD), peserta didik mengalami pengalaman negatif dan kurang menyanangkan, bahkan mungkin membuat mereka kapok untuk melakukan aktivitas jasmani, hal ini terjadi karena disamping pembelajarannya kurang menarik, tidak mengandung unsur permainan, tidak menggunakan media yang menarik dan cenderung membuat peserta didik merasa terbebani dalam pelaksanaannya.

Pada pengamatan awal dalam proses pembelajaran melompat pada mata pelajaran pendidikan jasmani olahraga dan kesehatan materi gerak dasar lompat pada peserta didik kelas V (lima) SDN Sungai Langsat Kabupaten Banjar, terdapat sekitar 57\% dengan nilai ratarata dibawah nilai KKM yaitu 70 hal ini disebabkan, peserta didik yang malas dalam mengikuti pelajaran gerak dasar lompat sehingga nilainya kurang dari cukup, dengan rincian peserta didik sebagai berikut: dari jumlah keseluruhan peserta didik 18 orang (putra7 orang dan putri 11 orang).

Pembelajaran pendidikan jasmani, olahraga dan kesehatan di SDN Sungai Langsat Kabupaten Banjar khususnya gerak dasar melompat biasanya sangatlah rumit ini 
dikarenakan kurangnya pemahaman guru tentang hakekat pembelajaran penjas serta pemilihan materi, metode dan media pembelajaran yang kurang sesuai dengan tingkat perkembangan peserta didik, belum lagi keterbatasan sarana dan prasarananya, misalnya lapangan dan alat-alat pendukung pembelajaran lainnya, sehingga pembelajaran menjadi tidak efektif dan tidak berkualitas, ini akan berakibat rendahnya kemampuan peserta didik dalam berbagai aspek perkembangan, aspek kognitif, afektif dan psikomotor yang seharusnya dia kuasai dengan baik, ini dapat dilihat dari banyaknya peserta didik yang malas dalam melaksanakan pembelajaran yang berakibat rendahnya kemampuan penguasaan gerak, selain melelahkan metode yang sebelumnya dipakai juga membosankan, guru tidak bisa dengan mudah menyuruh atau mengarahkannya agar peserta didik berlari sesuai arahan dan contoh tanpa ada hal-hal yang menarik bagi mereka, seperti media, metode pembelajaran atau cerita, karena pada hakekatnya peserta didik-peserta didik senang bermain, mengikuti aktivitas jasmani yang mengandung unsur permainan yang menggembirakan dan menyenangkan ditambah lagi media yang menarik bagi mereka tentunya menambah semangat mereka dalam bergerak, sehinggga mereka dapat melaksanakan didikan pembelajaran dengan baik tanpa merasa terbebani.

Berdasarkan uraian-uraian diatas, pembelajaran gerak dasar lompat menarik untuk dikaji bersama sehingga perkembangan peserta didik menjadi lebih baik dalam melakukan gerak dasar melompat. Sedangkan masalah yang khusus menarik untuk dibahas bersama dengan judul "Peningkatan Hasil Belajar Gerak Dasar Melompat Melalui Model Pembelajaran Kooperatif Terhadap Peserta Didik Kelas V Di SDN Sungai Langsat Kabupaten Banjar tahun pelajaran 2019/2020.

\section{METODE}

Menurut Harjodipuro dalam Budimansyah (2010:06) menyatakan PTK adalah: Suatu pendekatan untuk memperbaiki pendidikan melalui perubahan, dengan mendorong para guru untuk memikirkan praktek mengajarnya sendiri, agar kritis terhdap praktek tersebut dan agar mau mengubahnya. PTK bukan sekedar mengajar, PTK mempunyai makna sadar dan kritis terhadap dirinya sendiri untuk bersiap terhadap dirinya sendiri untuk bersiap terhadap proses perubahan dan proses perbaikan proses pembelajaran.

Menurut Arikunto (2006:2-3) Menyatakan bahwa Penelitian Tindakan Kelas (PTK) merupakan suatu pencermatan terhadap kegiatan pembelajaran berupa sebuah tindakan, yang sengaja di munculkan dan terjadi dalam sebuah kelas secara bersamaan.

Menurut Arikunto (2006:33) Tujuan Penelitian Tindakan Kelas (PTK):

1. Memperbaiki dan meningkatkan mutu isi, masukan, proses, serta hasil pendidikan dan pembelajaran di kelas, sekolah.

2. Membantu guru atau dosen, serta tenaga pendidikan lainnya mengatasi masalah pembelajaran di dalam dan luar kelas.

3. Mencari jawaban secara ilmiah (rasional, sistematis, empiris) mengapa masalah tersebut dapat dipecahkan melalui tindakan.

4. Meningkatkan sikap profesionalisme sebagai pendidik.

5. Menumbuh kembangkan budaya akademik di lingkungan sekolah, sehingga tercipta perbaikan dan peningkatan mutu atau kualitas pembelajaran secara berkelanjutan. 


\section{HASIL PENELITIAN}

\section{Temuan Hasil Pengamatan Awal}

Sebelum melakukan tindakan penelitian, peneliti melakukan observasi awal kelas. Hasil observasi awal menunjukkan bahwa hasil belajar peserta didik kelas V (lima) di SDN Sungai Langsat Kabupaten Banjar pada mata pelajaran pendidikan jasmani masih tergolong rendah. Berdasarkan hal tersebut maka diputuskan untuk menggunakan metode kooperatif yaitu pembelajaran yang berbasis masalah, pengalaman belajar dan pembelajaran yang modern untuk meningkatkan keterampilan dan hasil belajar gerak dasar melompat kelas V (lima) di SDN Sungai Langsat Kabupaten Banjar.

Pelaksanaan dilakukan pada jam pelajaran kelas V (lima) dimulai dari jam 08.00-10,00 WITA. Rencana pelaksanaan pembelajaran dilaksanakan seperti terdapat pada lampiran, dengan evaluasi pada saat pembelajaran berlangsung dan pada akhir pembelajaran. Apabila hasil evaluasi pada siklus pertama dinyatakan masih banyak perbaikan, maka akan dilanjutkan ke siklus berikutnya, hingga seluruh peserta didik mendapatkan pengalaman pembelajaran yang menarik, menyenangkan serta mengalami peningkatan kemampuan keterampilan dan hasil belajar gerak dasar melompat maka sudah dianggap berhasil dan penelitian akan dihentikan.

Pembelajaran dimulai dengan mangadakan tes awal kelas V (lima) untuk mengetahui kemampuan awal peserta didik pada materi gerak dasar melompat. Nilai tes awal dijadikan acuan untuk mengetahui hasil belajar peserta didik kelas V (lima) setelah menggunakan metode kooperatif. Berikut disajikan data hasil belajar peserta didik Pra siklus mengenai penguasaan gerak peserta didik pada tabel 1.

Tabel 1. Data nilai pengamatan awal pembelajaran gerak dasar melompat pada peserta didik kelas V (lima) SDN Sungai Langsat Kabupaten Banjar

\begin{tabular}{|c|c|c|c|c|c|c|c|c|c|c|c|c|c|c|c|c|c|c|}
\hline \multirow{4}{*}{ NO } & \multirow{4}{*}{ NAMA } & \multirow{2}{*}{\multicolumn{14}{|c|}{$\begin{array}{c}\text { KUALITAS GERAK } \\
\text { Psikomotor }\end{array}$}} & \multirow{4}{*}{ Jlh } & \multirow{4}{*}{$\begin{array}{c}\text { Rata } \\
\text { - rata }\end{array}$} & \multirow{4}{*}{$\begin{array}{c}\text { Tuntas = } \\
\text { KKM (70) }\end{array}$} \\
\hline & & & & & & & & & & & & & & & & & & \\
\hline & & \multicolumn{4}{|c|}{ A } & \multicolumn{4}{|c|}{ B } & \multicolumn{4}{|c|}{$\mathrm{C}$} & \multicolumn{2}{|c|}{ D } & & & \\
\hline & & 1 & 2 & 3 & 4 & 1 & 2 & 3 & 4 & 1 & 2 & 3 & 4 & 2 & 3 & & & \\
\hline 1 & A. Diraya Zikri & & 2 & & & 2 & & & & & & 3 & & 2 & & 11 & 68 & Tdk Tuntas \\
\hline 2 & A. Jarkani & & & 3 & & & 3 & & & & & 3 & & & & 13 & 81 & Tuntas \\
\hline 3 & A. Ridho & & 2 & & & & 3 & & & & & 3 & & & & 12 & 75 & Tuntas \\
\hline 4 & A. Arya Nurulloh & & 2 & & & 2 & & & & & & 3 & & 2 & & 11 & 68 & Tdk Tuntas \\
\hline 5 & Alfiansyah & & & 3 & & & 3 & & & & & 3 & & & 3 & 12 & 75 & Tuntas \\
\hline 6 & Aulia Ramadhan & & & 3 & & 2 & & & & & & 3 & & & 3 & 11 & 68 & Tdk Tuntas \\
\hline 7 & Azkiya & & & 3 & & 2 & & & & & & 3 & & 2 & & 10 & 62 & Tdk Tuntas \\
\hline 8 & Eva & & 2 & & & & & 3 & & & & 3 & & 2 & & 10 & 62 & Tdk Tuntas \\
\hline 9 & Jahrah & & 2 & & & & 2 & & & & 2 & & & 2 & & 8 & 50 & Tdk Tuntas \\
\hline 10 & Mina & & & & 4 & & & & 4 & & & & 4 & & & 16 & 100 & Tuntas \\
\hline 11 & Nursyfa & & & & 4 & & & 3 & & & & 3 & & & & 14 & 87 & Tuntas \\
\hline 12 & Rusdi & & & 3 & & & 3 & & & & 2 & & & 2 & & 10 & 62 & Tdk Tuntas \\
\hline 13 & Salsabila & & & 3 & & & 3 & & & & 2 & & & 2 & & 10 & 62 & Tdk Tuntas \\
\hline 14 & Santi & & 2 & & & 2 & & & & & & 3 & & 2 & & 9 & 56 & Tdk Tuntas \\
\hline 15 & Sariah & & & 3 & & & 3 & & & & & 3 & & 2 & & 11 & 68 & Tdk Tuntas \\
\hline 16 & Selamat & & 2 & & & 2 & & & & & & 3 & & & 3 & 10 & 62 & Tdk Tuntas \\
\hline 17 & Sirli & & 2 & & & 2 & & & & & & 3 & & & 3 & 10 & 62 & Tdk Tuntas \\
\hline \multirow[t]{6}{*}{18} & Yuli & & & & 4 & & & 3 & & & & & 4 & & 3 & 14 & 87 & Tuntas \\
\hline & Jumlah & & & & & & & & & & & & & & & & 1152 & \\
\hline & \multicolumn{16}{|c|}{ Rata - Rata } & 64 & \\
\hline & \multicolumn{16}{|c|}{ Nilai Tertinggi } & 100 & \\
\hline & \multicolumn{16}{|c|}{ Nilai Terendah } & 50 & \\
\hline & \multicolumn{16}{|c|}{ Ketuntasan } & $33 \%$ & \\
\hline
\end{tabular}



Keterangan:
$\mathrm{A}=$ Gerakan awalan melompat
$\mathrm{B}=$ Gerakan tolakan pada saat melompat
$\mathrm{C}=$ Gerakan melayang pada saat melompat
$\mathrm{D}=$ Gerakan mendarat setelah melompat

Hal ini disebabkan oleh beberapa hal yaitu:

1. Rendahnya hasil pembelajaran penjasorkes khususnya gerak dasar lompat pada peserta didik kelas V (lima) SDN Sungai Langsat Kabupaten Banjar.

2. Kurangnya metode pembelajaran gerak dasar lompat yang tepat dan sesuai untuk peserta didik kelas V (lima) SDN Sungai Langsat Kabupaten Banjar.

3. Sarana dan prasarana yang kurang memadai dan mendukung kelancaran proses pembelajaran melompat sehingga proses pembelajaran melompat tidak sesuai dengan KKM yang ditetapkan guru SDN Sungai Langsat Kabupaten Banjar.

4. Rendahnya kemampuan gerak dasar lompat peserta didik kelas V (lima) SDN Sungai Langsat Kabupaten Banjar.

5. Kurangnya variasi dan inovasi pembelajaran yang menarik sehingga membuat peserta didik kelas V (lima) SDN Sungai Langsat Kabupaten Banjar banyak yang malas dalam melaksanakan pembelajaran penjasorkes.

\section{Perencanaan Tindakan}

1. Sebelum meyusun rencana pembelajaran, peneliti melakukan identifikasi masalah dan merencanakan langkah-langkah yang akan dilaksanakan pada siklus I (satu).

2. Setelah peneliti mengetahui masalah dan langkah-langkah yang akan digunakan pada tindakan di siklus I (satu), peneliti kemudian membuat Rencana Pelaksanaan Pembelajaran (RPP).

3. Menentukan metode, serta langkah-langkah yang tepat pada peneilitian.

4. Mengembangkan Rencana Pelaksanaan Pembelajaran.

5. Mengembangkan Format Evaluasi dan Mengembangkan Format Observasi.

\section{Pelaksanaan Tindakan}

Pelaksanaan tindakan pada siklus I (satu) dilaksanakan sebagai berikut:

\section{Temuan Siklus I (satu)}

Dilaksanakan pada: Senin tanggal 21 Januari 2019 di SDN Sungai Langsat Kabupaten Banjar pada Peserta didik kelas V (lima) berjumlah 18 orang.

1) Tahap I Kegiatan Awal

Tahap ini diawali dengan Guru terlebih dahulu meneliti tingkat kesiapan pesera didik, mengecek absensi peserta didik serta mengkondisikan peserta didik agar pembelajaran dapat berlangsung secara kondusif. Kemudian guru melakukan apersepsi dengan tanya jawab tentang materi yang akan diajarkan, misalnya tanya jawab tentang permainan yang sering dilakukan peserta didik dalam kehidupan sehari-hari.

2) Tahap II Kegiatan Inti 
Guru selanjutnya memandu peserta didik untuk mempraktekkan pembelajaran gerak dasar melompat dengan menerapkan metode kooperatif. Guru akan menggali pengetahuan dari peserta didik dan jika ada peserta didik yang mengalami kesulitan, teman yang dianggap mampu memberikan contoh untuk gerakan tersebut.

3) Tahap III Kegiatan Akhir

Guru menutup pembelajaran dengan membimbing peserta didik untuk menarik kesimpulan dari materi yang disampaikan, kemudian memberikan evaluasi berupa tes tentang melompat.

\section{Observasi}

Dari hasil observasi siklus I (satu), didapatkan bahwa dalam melaksanakan pembelajaran PJOK dengan menggunakan metode kooperatif pada siklus I (satu), guru menerapkan sesuai dengan Rencana Pelaksanaan Pembelajaran (RPP) yang telah disiapkan. Berdasakan hasil pengamatan oleh observer, guru kurang jelas dalam menerapkan intruksi dan langkah-langkah pembelajaran. Masalah lain yang didapat dari pengamatan observer adalah pada saat menjelaskan masih ada peserta didik yang kurang memperhatikan. Berikut disajikan data hasil belajar peserta didik kurang menguasai teknik pembelajaran gerak dasar melompat:

Tabel 2. Penilaian Siklus I ( Satu ) Gerak dasar melompat Pada Peserta Didik Kelas V (lima) SDN Sungai Langsat Kabupaten Banjar

\begin{tabular}{|c|c|c|c|c|c|c|c|c|c|c|c|c|c|c|c|c|c|c|}
\hline \multirow{4}{*}{ NO } & \multirow{4}{*}{ NAMA } & \multirow{2}{*}{\multicolumn{14}{|c|}{$\begin{array}{c}\text { KUALITAS GERAK } \\
\text { Psikomotor }\end{array}$}} & \multirow{4}{*}{ Jlh } & \multirow{4}{*}{$\begin{array}{c}\text { Rata - } \\
\text { rata }\end{array}$} & \multirow{4}{*}{$\begin{array}{c}\text { Tuntas = } \\
\text { KKM (70) }\end{array}$} \\
\hline & & & & & & & & & & & & & & & & & & \\
\hline & & \multicolumn{4}{|c|}{ A } & \multicolumn{4}{|c|}{ B } & \multicolumn{3}{|c|}{$\mathrm{C}$} & \multicolumn{3}{|l|}{ D } & & & \\
\hline & & 1 & 2 & 3 & 4 & 1 & \begin{tabular}{l|l}
2 & \\
\end{tabular} & 3 & 1 & \begin{tabular}{l|l}
1 & 2
\end{tabular} & 3 & 4 & 1 & 2 & 3 & & & \\
\hline 1 & A. Diraya Zikri & & & 3 & & 2 & & & & & 3 & & & & 3 & 11 & 68 & Tdk Tuntas \\
\hline 2 & A. Jarkani & & & 3 & & & 3 & & & & 3 & & & & & 13 & 81 & Tuntas \\
\hline 3 & A. Ridho & & 2 & & & & 3 & & & & 3 & & & & & 12 & 75 & Tuntas \\
\hline 4 & A. Arya Nurulloh & & 2 & & & 2 & & & & & 3 & & & 2 & & 11 & 68 & Tdk Tuntas \\
\hline 5 & Alfiansyah & & & 3 & & & 3 & & & & 3 & & & & 3 & 12 & 75 & Tuntas \\
\hline 6 & Aulia Ramadhan & & & 3 & & 2 & & & & & 3 & & & & 3 & 11 & 68 & Tdk Tuntas \\
\hline 7 & Azkiya & & & 3 & & 2 & & & & & 3 & & & 2 & & 10 & 62 & Tdk Tuntas \\
\hline 8 & Eva & & 2 & & & & 3 & & & & 3 & & & & & 12 & 75 & Tuntas \\
\hline 9 & Jahrah & & 2 & & & & 2 & & & 2 & & & & 2 & & 9 & 56 & Tdk Tuntas \\
\hline 10 & Mina & & & & 4 & & & 4 & 4 & & & 4 & & & & 16 & 100 & Tuntas \\
\hline 11 & Nursyfa & & & & 4 & & & 3 & & & 3 & & & & & 14 & 87 & Tuntas \\
\hline 12 & Rusdi & & & 3 & & & 3 & & & 2 & & & & 2 & & 10 & 62 & Tdk Tuntas \\
\hline 13 & Salsabila & & 2 & & & & 3 & & & & 3 & & & & & 12 & 75 & Tuntas \\
\hline 14 & Santi & & 2 & & & 2 & & & & & 3 & & & 2 & & 9 & 56 & Tdk Tuntas \\
\hline 15 & Sariah & & 2 & & & & 3 & & & & 3 & & & & & 12 & 75 & Tuntas \\
\hline 16 & Selamat & & 2 & & & & 3 & & & & 3 & & & & & 12 & 75 & Tuntas \\
\hline 17 & Sirli & & 2 & & & 2 & & & & & 3 & & & & 3 & 10 & 62 & Tdk Tuntas \\
\hline \multirow[t]{6}{*}{18} & Yuli & & & & 4 & & & 3 & & & & 4 & & & 3 & 14 & 87 & Tuntas \\
\hline & Jumlah & & & & & & & & & & & & & & & & 1224 & \\
\hline & \multicolumn{16}{|c|}{ Rata - Rata } & 68 & \\
\hline & \multicolumn{16}{|c|}{ Nilai Tertinggi } & 100 & \\
\hline & \multicolumn{16}{|c|}{ Nilai Terendah } & 50 & \\
\hline & \multicolumn{16}{|c|}{ Ketuntasan } & & $52 \%$ \\
\hline
\end{tabular}

Berdasarkan tabel dan grafik diatas, terlihat peserta didik hanya memperoleh rata-rata 68 dengan nilai tertinggi 100 dan nilai terendah 62 peserta didik. Hasil belajar pada siklus I 
(satu) hanya ada 10 peserta didik yang mencapai nilai KKM yang ditetapkan yaitu 70. Hal ini memberi gambaran bahwa hasil belajar peserta didik pada materi gerak dasar melompat dengan menggunakan metode kooperatif sehingga mendapat peningkatan keberhasilan jika dibandingkan dengan hasil pengamatan awal walaupun masih belum maksimal.

\section{Refleksi}

Setelah peneliti melakukan serangkaian kegiatan proses belajar mengajar gerak dasar melompat di SD Negeri Sungai Langsat Kabupaten Banjar, peneliti mengajak supervisor dan teman-teman sejawat yang sudah secara langsung memperhatikan dan menilai proses kegiatan belajar mengajar untuk memberikan penilaiannya secara langsung baik berupa sumbang pendapat ataupun kritik yang membangun peneliti untuk melakukan proses belajar mengajar yang lebih baik lagi sehingga kemampuan keterampilan peserta didik makin meningkat. Adapun sumbang saran dari supervisor adalah sebagai berikut:

1. Lebih menggali permainan yang mengarah pada materi Gerak dasar melompat dan memberikan banyak kesempatan peserta didik untuk menggali masalah dan memecahkan masalah pada saat pembelajaran, sehingga kebutuhan utama peserta didik terpenuhi.

2. Tegas dalam memberikan materi secara tahap demi tahap atau bagian ke bagian sebelum materi secara keseluruhan.

3. Ketika melakukan proses belajar mengajar agar jangan melakukan tindakan yang bisa membuat peserta didik bosan.

4. Metode kooperatif memang sangat tepat digunakan, tetapi jangan melupakan keterbatasan waktu yang tersedia.

5. Lebih memfokuskan materi gerak dasar melompat menggunakan metode kooperatif.

Dari hasil siklus I (satu) ini hanya 10 orang mendapat nilai diatas 70 di kategorikan tuntas sedangkan 8 orang mendapat nilai di bawah 70 atau di kategorikan tidak tuntas Sehingga di dapatkan siklus I (satu) hasil rata-rata nilai pembelajaran masih di bawah KKM yang di tentukan guru yaitu 70. Maka peneliti akan melanjutkan ke siklus berikutnya dengan beberapa perbaikan sampai target pencapaian KKM yang di tentukan pada pembelajaran gerak dasar lompat terpenuhi.

\section{Temuan Siklus II (dua)}

Dilaksanakan pada: Senin, 28 Januari 2019 di SDN Sungai Langsat Kabupaten Banjar pada Peserta didik kelas V (lima) berjumlah 18 orang.

1) Tahap I Kegiatan Awal

Tahap ini diawali dengan Guru terlebih dahulu meneliti tingkat kesiapan peserta didik, guru memberikan salam kepada peserta didik, mengecek absensi peserta didik serta mengkondisikan peserta didik agar pembelajaran dapat berlangsung secara kondusif.

Kemudian guru melakukan apersepsi dengan tanya jawab tentang materi yang akan diajarkan, misalnya tanya jawab tentang permainan yang sering dilakukan peserta didik dalam kehidupan sehari-hari yang berkaitan dengan pembelajaran gerak dasar melompat.

Guru memberikan arahan tentang pelaksanaan kegiatan yang akan dilaksanakan, kemudian melakukan pemanasan antara lain: melakukan pemanasan bermain ayam dan 
musang, latihan loncat-loncat di tempat, latihan lompat tanpa awalan dan latihan lari di variasi dengan gerakan melompat biasa dengan mendarat pada kaki sejajar.

2) Tahap II Kegiatan Inti

Guru selanjutnya menjelaskan materi secara singkat tentang melompat, mengenai awalan, sampai mendarat. Guru memandu peserta didik untuk mempraktekkan pembelajaran gerak dasar melompat dengan menggunakan berbagai rintangan yang peserta didik dapat mempelajari setiap gerakan yang dilakukan. Peserta didik juga diharapkan dapat menemukan dan memecahkan masalah yang dihadapi sendiri pada saat pelaksanaan sehingga metode kooperatif dapat diterapkan dengan baik.

3) Tahap III Kegiatan Akhir

Guru menutup pembelajaran dengan membimbing peserta didik untuk menarik kesimpulan dari materi yang disampaikan, kemudian memberikan evaluasi berupa tes tentang gerak dasar melompat.

\section{Observasi}

Dari hasil observasi siklus I (satu), didapatkan bahwa dalam melaksanakan pembelajaran Pendidikan Jasmani dengan menggunakan metode kooperatif pada siklus I (satu), guru menerapkan sesuai dengan Rencana Pelaksanaan Pembelajaran (RPP) yang telah disiapkan. Berdasakan hasil pengamatan oleh observer, guru kurang jelas dalam menerapkan intruksi dan langkah-langkah pembelajaran. Masalah lain yang didapat dari pengamatan observer adalah pada saat menjelaskan masih ada peserta didik yang kurang memperhatikan. Berikut disajikan data hasil belajar peserta didik masih banyak kurang menguasai teknik pembelajaran melompat, hal ini diakibatkan berdasarkan pengamatan observer perlu adanya pengulangan beberapa teknik dasar melompat. Karena di dapatkan hasil yang sudah sesuai dengan nilai yang ingin dicapai peneliti maka penelitian dihentikan pada siklus II (dua), berikut dapat di sajikan hasil penilaian siklus II (dua):

Tabel 3. Penilaian Siklus II (dua) gerak dasar melompat pada peserta didik Kelas V (lima)

\begin{tabular}{|c|c|c|c|c|c|c|c|c|c|c|c|c|c|c|c|c|c|c|c|}
\hline \multirow{4}{*}{ NO } & \multirow{4}{*}{ NAMA } & \multirow{2}{*}{\multicolumn{15}{|c|}{ KUALITAS GERAK }} & \multirow{4}{*}{$\mathbf{J l h}$} & \multirow{4}{*}{$\begin{array}{l}\text { Rata - } \\
\text { rata }\end{array}$} & \multirow{4}{*}{$\begin{array}{c}\text { Tuntas = } \\
\text { KKM (70) }\end{array}$} \\
\hline & & \multirow{2}{*}{\multicolumn{4}{|c|}{ Psikomotor }} & & & & & & & & & & & & & & \\
\hline & & \multicolumn{4}{|c|}{$\mathbf{A}$} & \multirow{2}{*}{\multicolumn{4}{|c|}{ B }} & \multicolumn{4}{|c|}{$\mathrm{C}$} & \multicolumn{2}{|c|}{ D } & & & & \\
\hline & & $\mathbf{1}$ & 2 & 3 & 4 & & & & 4 & $\mathbf{1}$ & 2 & 3 & 4 & $\mathbf{1}$ & 2 & 3 & & & \\
\hline 1 & A. Diraya Zikri & & 2 & & & & 3 & & & & & 3 & & & & & 13 & 81 & Tuntas \\
\hline 2 & A. Jarkani & & & & 4 & & & & 4 & & & & 4 & & & & 16 & 100 & Tuntas \\
\hline 3 & A. Ridho & & 2 & & & & 3 & & & & & 3 & & & & & 12 & 75 & Tuntas \\
\hline 4 & A. Arya Nurulloh & & 2 & & & & 3 & & & & & 3 & & & & & 12 & 75 & Tuntas \\
\hline 5 & Alfiansyah & & & 3 & & & 3 & & & & & 3 & & & & 3 & 12 & 75 & Tuntas \\
\hline 6 & Aulia Ramadhan & & & 3 & & & 3 & & & & & 3 & & & & & 13 & 81 & Tuntas \\
\hline 7 & Azkiya & & & & 4 & & & & 4 & & & & 4 & & & & 16 & 100 & Tuntas \\
\hline 8 & Eva & & & & 4 & & & & 4 & & & & 4 & & & & 16 & 100 & Tuntas \\
\hline 9 & Jahrah & & 2 & & & & 3 & & & & & 3 & & & & & 12 & 75 & Tuntas \\
\hline 10 & Mina & & & & 4 & & & & 4 & & & & 4 & & & & 16 & 100 & Tuntas \\
\hline 11 & Nursyfa & & & & 4 & & & & 4 & & & & 4 & & & & 16 & 100 & Tuntas \\
\hline 12 & Rusdi & & 2 & & & & 3 & & & & & 3 & & & & & 12 & 75 & Tuntas \\
\hline 13 & Salsabila & & & & 4 & & & & 4 & & & & 4 & & & & 16 & 100 & Tuntas \\
\hline 14 & Santi & & 2 & & & & 3 & & & & & 3 & & & & & 12 & 75 & Tuntas \\
\hline 15 & Sariah & & 2 & & & & 3 & & & & & 3 & & & & & 12 & 75 & Tuntas \\
\hline 16 & Selamat & & 2 & & & & 3 & & & & & 3 & & & & & 13 & 81 & Tuntas \\
\hline 17 & Sirli & & 2 & & & & 3 & & & & & 3 & & & & & 12 & 75 & Tuntas \\
\hline \multirow[t]{6}{*}{18} & Yuli & & & & 4 & & & & 4 & & & & 4 & & & & 16 & 100 & Tuntas \\
\hline & Jumlah & & & & & & & & & & & & & & & & & 1529 & \\
\hline & \multicolumn{17}{|c|}{ Rata - Rata } & 84,95 & \\
\hline & \multicolumn{17}{|c|}{ Nilai Tertinggi } & 100 & \\
\hline & \multicolumn{17}{|c|}{ Nilai Terendah } & 75 & \\
\hline & \multicolumn{18}{|c|}{ Ketuntasan } & $100 \%$ \\
\hline
\end{tabular}

Berdasarkan tabel dan grafik diatas, terlihat peserta didik hanya memperoleh rata-rata 84,95 dengan nilai tertinggi 100 dan nilai terendah 75 peserta didik. Hasil belajar pada siklus 
II (dua) ada 18 peserta didik yang mencapai nilai KKM yang ditetapkan yaitu 70. Hal ini memberi gambaran bahwa hasil belajar peserta didik pada materi gerak dasar melompat dengan menggunakan metode kooperatif sudah berhasil dengan pengamatan siklus II (dua) sudah maksimal.

\section{Temuan Lengkap}

Setelah mendapatkan sumbang saran yang sangat berharga dari supervisor maka peneliti mengevaluasi diri dan mencoba untuk melakukan perbaikkan agar tujuan dari penelitian ini dapat tercapai.

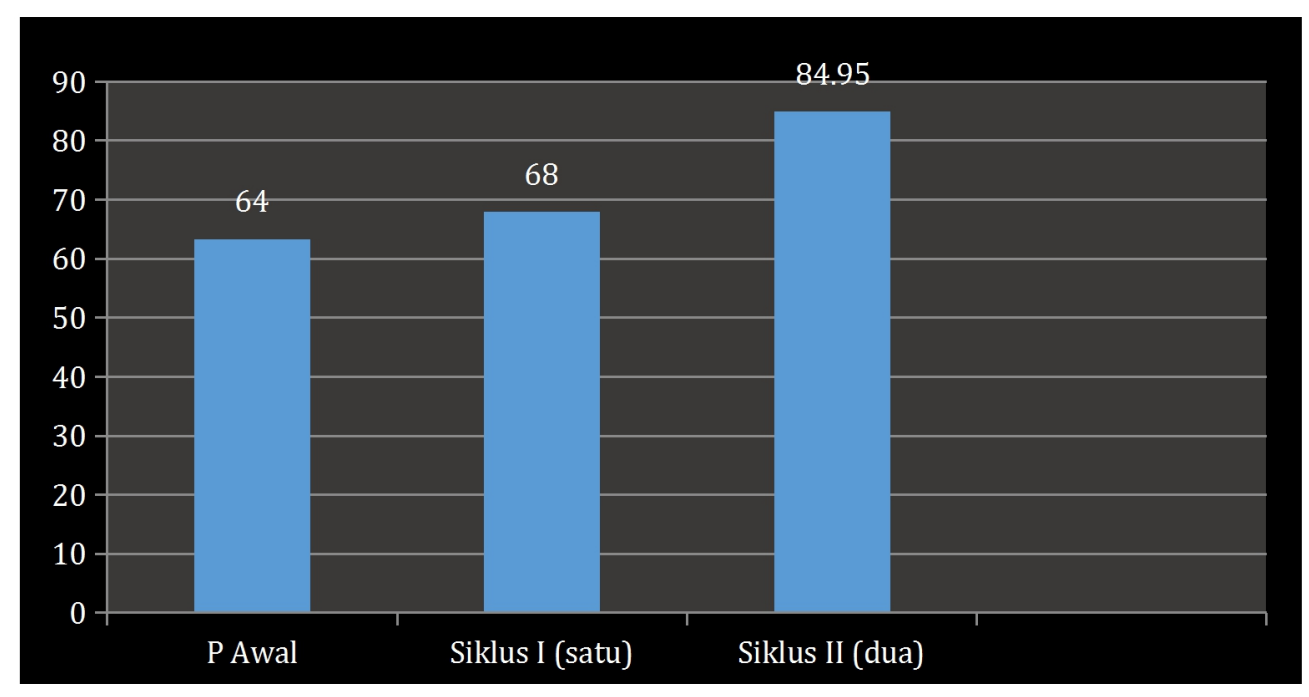

Gambar 1. Peningkatan Nilai Rata-rata Pengamatan Awal nilai gerak dasar melompat pada peserta didik kelas V (lima) di SD Negeri Sungai Langsat Kabupaten Banjar

Dari gambar diatas terlihat bahwa terjadi peningkatan dalam pembelajaran melakukan gerak dasar melompat. Pada pengamatan awal masih banyak gerakan peserta didik yang belum benar, pada pertemuan siklus I (satu) terjadi perbaikkan gerakan sehingga mengalami peningkatan, dan pada siklus II (dua) melakukan gerakan dasar melompat pada peserta didik kelas V (lima) SD Negeri Sungai Langsat Kabupaten Banjar rata-rata baik dan sesuai dengan harapan.

Pada pengamatan awal nilai penguasaan tugas gerak yang diberikan guru kepada peserta didik diperoleh nilai rata-rata seluruh peserta didik sebesar 64 yang merupakan kategori K (Kurang), nilai terendah yang didapatkan yaitu 53,33 dan nilai yang tertinggi 100 dari 18 hanya 6 orang yang peserta didik yang mencapai nilai KKM yang sudah ditetapkan yaitu 70.

Pada siklus I (satu) nilai penguasaan tugas gerak yang diberikan guru kepada peserta didik diperoleh nilai rata-rata seluruh peserta didik sebesar 68 dengan katagori K (Kurang), nilai terendahnya yaitu 56 dan nilai tertinggi yaitu 100 dari 18 peserta didik ada 11 orang yang mencapai nilai KKM. Pada siklus I (satu) mendapat nilai 68 sedangkan pada siklus II (dua) diperoleh nilai rata-rata seluruh peserta didik sebesar 84,95 dengan kategori A (sangat baik) nilai terendah dari 18 peserta didik yaitu 75 dan yang tertinggi dengan nilai 100 ini 
artinya kemampuan peserta didik secara keseluruhan sudah meningkat terlihat dari data bahwa seluruh peserta didik sudah mencapai nilai KKM yang ditetapkan yaitu 70 atau ketuntasan belajar sudah mencapai 100\%. Sehingga pembelajaran gerak dasar melompat dianggap tuntas, pada peserta didik kelas V (lima) di SD Negeri Sungai Langsat Kabupaten Banjar.

\section{PEMBAHASAN}

Pada saat melakukan peneliti gerakan dasar melompat saat menggunakan metode kooperatif, dengan jumlah peserta didik 18 orang dalam proses kegiatan belajar mengajar ditemukan hasil sebagai berikut. Analisis data ditemukan bahwa hasil penilaian kemampuan peserta didik menunjukkan peningkatan kemampuan peserta didik ditunjukkan dari hasil penilaian pengamatan awal jumlah nilai 1152 dengan rata-rata 64 (kurang) persentase ketuntasan 33\%, pertemuan Siklus I (satu) jumlah nilai 1224 dengan rata-rata 68 (cukup) persentase ketuntasan 52\% dan pertemuan siklus II (dua) jumlah nilai 1529 dengan rata-rata 84,95 (sangat baik) persentase ketuntasan 100\%.

Pada siklus I (satu) dilakukan pembelajaran dengan melaksanakan gerak dasar melompat dengan metode pembelajaran kooperatif. Metode pembelajaran ini menekankan pada pembelajaran berkelompok untuk memudahkan mempraktikkan dan memahami awalan, tumpuan, melayang, dan mendarat pada pembelajaran gerak dasar melompat. Pada siklus I ini guru peneliti sudah melaksanakan pembelajaran sesuai dengan RPP, akan tetapi peserta didik masih ragu-ragu dan belum siap melakukan kegiatan gerak dasar melompat dengan metode pembelajaran kooperatif. Hasil diskusi dan tanya jawab diperoleh kesimpulan bahwa peserta didik masih perlu berlatih gerak dasar melompat sesering mungkin. Pada pelaksanaan tindakan ternyata peserta didik belum terbiasa mengambil kesimpulan dari kegiatan yang dilakukan, pada saat pembelajaran gerak dasar melompat melalui metode pembelajaran koopeatif dan berdiskusi juga masih di dominasi satu dua orang peserta didik, masih ada materi yang belum di kuasai peserta didik.

Pada siklus II dilakukan pembelajaran gerak dasar melompat dengan metode pembelajaran koopeatif sesuai dengan refleksi pada siklus I, proses pembelajaran berjalan lancar, dan menyenangkan guru dan peserta didik pelajaran berjalan dengan gembira. Peserta didik aktif melakukan kegiatan bermain dan saling bertukar pikiran dengan peserta didik lainnya. Pada pelaksanaan siklus II, diketahui peserta didik sudah dapat melakukan proses pembelajaran dengan metode pembelajaran koopertif atau bekerjasama dengan gembira dan penuh semangat dengan peningkatan aktivitas yang efektif dengan di tandai adanya peningkatan hasil belajar peserta didik dengan ketuntasan mencapai 80\%. Dari jumlah peserta didik kelas V (lima) di SD Negeri Sungai Langsat Kabupaten Banjar sebanyak 18 peserta didik sudah mendapatkan nilai hasil belajar di atas batas nilai KKM yaitu 70 sesuai dengan K13 peserta didik kelas V (lima) di SD Negeri Sungai Langsat Kabupaten Banjar.

Setelah dilakukan penelitian tindakan selama 2 siklus dan tiap siklus dilakukan tes untuk memperoleh hasil belajar gerak dasar melompat, maka diperoleh data sebagai berikut: Dari hasil refleksi siklus I peserta didik masih ragu-ragu dan belum memahami pola pembelajaran gerak dasar melompat dengan metode pembelajaran kooperatif. Pelaksanaan pembelajaran belum maksimal karena masih ada peserta didik yang tidak memperhatikan 
pembelajaran dan ada beberapa materi yang belum dikuasai oleh beberapa peserta didik. Walaupun guru sudah melakukan perannya sesuai dengan perencanaan dan model pembelajaran sudah tepat, secara keseluruhan tujuan pembelajaran belum tercapai maksimal.

Dari hasil sharing ideas dengan supervisor tentang pelaksanaan proses pembelajaran dan hasil belajar pada siklus II diperoleh hasil refleksi: peserta didik sudah mulai terbiasa dengan pembelajaran yang menggunakan metode pembelajaran kooperatif peserta didik lebih semangat aktif dan kreatif dalam proses pembelajaran. Guru semakin mengerti kelemahannya dan terus mencari alternative pemecahannya proses pembelajaran sudah sesuai dengan RPP dan guru sudah melakukan perannya sesuai dengan model pembelajaran yang diterapkan secara keseluruhan tujuan pembelajaran sudah tercapai sesuai dengan rencana setelah dilakukan tindakan siklus II yang merupakan refleksi dari siklus I pada siklus II hasil pembelajaran gerak dasar melompat peserta didik mengalami peningkatan hingga 18 peserta didik (100\%) mendapat nilai di atas batas KKM dan dinyatakan tuntas.

Upaya peningkatan hasil belajar gerak dasar melompat berhasil dengan baik jika dilihat dari peningkatan pada tiap siklus yang rata-rata mencapai ketuntasan pada setiap siklus meningkat hasil belajar peserta didik yang paling besar pada siklus II, hal ini terjadi karena peserta didik sudah mulai memahami konsep pembelajaran gerak dasar melompat dengan pendekatan kooperatif peserta didik merasa senang dalam mengikuti pembelajaran sehingga hasil yang diperoleh peserta didik meningkat dan proses pembelajaran sudah berjalan sesuai dengan rencana dan hasil yang didapat juga sesuai dengan yang diharapkan.

Peningkatan efektifitas pembelajaran gerak dasar melompat dengan metode pembelajaran kooperatif terjadi karena dalam perbaikan pembelajaran secara konsekuen penulis melakukan aktifitas-aktifitas perbaikan pembelajaran dalam proses belajar mengajar antara lain sebagai berikut:

a) Menjelaskan materi pembelajaran dengan pelan dan menggunakan bahasa yang mudah dipahami peserta didik.

b) Menggunakan metode pembelajaran koopertif karena anak usia SD senang dengan bermain dengan berkelompok .

c) Pemanfaatan media yang tepat dan menarik

d) Pelaksanaan pemberian bimbingan yang sesuai.

e) Pemberian tugas dan latihan.

\section{SIMPULAN}

Berdasarkan hasil penelitian yang telah dilakukan pada peserta didik kelas V (lima) SD Negeri Sungai Langsat Kabupaten Banjar, Tahun Pelajaran 2019/2020, bahwa kemampuan hasil belajar sgerak dasar melompat peserta didik sesudah guru menggunakan pendekatan Motode kooperatif ternyata efektif, ini dapat dilihat dari data yang diperoleh.

Dari uraian sebelumnya, didapat kesimpulan sebagai berikut:

1. Pada pengamatan awal nilai penguasaan tugas gerak yang diberikan guru kepada peserta didik diperoleh nilai rata-rata seluruh peserta didik sebesar 57 yang merupakan kategori $\mathrm{K}$ (Kurang), nilai terendah yang didapatkan yaitu 64 dan nilai yang tertinggi 100 dari 16 hanya 6 orang yang peserta didik yang mencapai nilai KKM yang sudah ditetapkan yaitu 70 . 
2. Metode pembelajaran kooperatif dapat meningkatkan hasil belajar gerak dasar lompat dengan rata-rata nilai pada siklus I (satu) 68,7> 64, dan $68<70$ (KKM) sehingga dinyatakan tidak tuntas.

3. Metode pembelajaran kooperatif dapat meningkatkan hasil belajar gerak dasar lompat dengan rata-rata nilai pada siklus II (dua) 84,95 > 68,7 dan atau 84,95 > 70 (KKM) sehingga dinyatakan tuntas.

4. Pembelajaran kooperatif yaitu pembelajaran yang dilakukan berkelompok sehingga peserta didik dapat bekerja sama dalam melakukan pembelajaran gerak dasar melompat sehingga memudahkan peserta didik untuk saling membantu satu sama lain sehingga pembelajaran gerak dasar lompat lebih mudah dikuasai.

\section{DAFTAR PUSTAKA}

Arikunto, S. 2006. Penelitian Tindakan Kelas. Bumi Aksara Jakarta.

Arikunto, S. 2010. Evaluasi Pendidikan Jasmani. Bumi Aksara Jakarta.

Depdiknas. 2003. Penelitian Tindakan Kelas Direktorat Pendidikan Dasar dan Menengah. Direktorat tenaga kependidikal. Departeman Pendidikan Nasional.

Depdiknas. 2004. Pedoman Pembelajaran Tuntas. Direktorat Pendidikan Lanjutan Pertama, Direktorat Jenderal Pendidikan Dasar dan Menengah, Departemen Pendidikan Nasional.

Djumidar, M., Widya, A. 2004. Belajar Berlatih Gerak-Gerak Dasar Atletik Dalam Bermain. Jakarata: Rajawali Sport.

Lelono, D. 2004. Penelitian Tindakan Kelas. ULM Banjarmasin.

Mashud, M. (2018). Analisis Masalah Guru PJOK Dalam Mewujudkan Tujuan Kebugaran Jasmani. Multilateral Jurnal Pendidikan Jasmani Olahraga, 17(2), 77-85. https://doi.org/10.20527/multilateral.v17i2.5704

Mashud, M. (2020). The Effectiveness of Physical Education Learning in Elementary School Located in Wetland Environment. Jurnal Pendidikan: Teori, Penelitian, Dan Pengembangan, 5(2), 265-270. https://doi.org/DOI: http://dx.doi.org/10.17977/jptpp.v5i2.13194

Melograno. 1996. (http://www.guruit07.blogspot.com/2013/01/pengertian-metode-paikempembelajaran.htm). diakses 7 September 2013

Lutan, R. 2001. Mengajar Pendidikan Jasmani, Pendekatan Pendidikan Gerak Di Sekolah Dasar. Jakarta. Departemen Pendidikan Nasional.

Suherman, A. 2001. Evaluasi Pendidikan Jasmani. Depertemen Pendidikan Nasional. Jakarta.

Yuliansyah. 2012. Peningkaatan Kualitas Pembelajaran Gerak Dasar Lari Melalui Pendekatan Metode Bermain Terhadap Peserta Didik SDN Gambut 5 Kecamatan Gambut. Hasil tidak diterbitkan. 